\title{
PENINGKATAN PERTUMBUHAN DAN PRODUKSI TANAMAN WORTEL (DAUCUS CAROTA L) DENGAN PENGGUNAAN PUPUK ORGANIK CAIR
}

\section{INCREASED GROWTH AND PRODUCTION OF CARROTS (DAUCUS CAROTA L) USING LIQUID ORGANIC FERTILIZERS}

\author{
Yustinus Nahak ${ }^{1)}$, Tatang Suryadi ${ }^{2)}$, Rika Despita ${ }^{2)}$ \\ 1) Dinas Tanaman Pangan, Hortikultura dan Perkerbunan Kab. Timur Tengah Selatan, NTT \\ 2) Dosen Politeknik Pembangunan Pertanian Malang \\ E-mail: rikadespita84@gmail.com
}

\begin{abstract}
ABSTRAK
Wortel merupakan sayuran umbi yang bernilai ekonomi tinggi di Indonesia. Upaya peningkatan kuantitas umbi dilakukan agar dapat memenuhi permintaan pasar. Penelitian ini bertujuan untuk mengetahui konsentrasi penggunaan pupuk organik cair yang mampu menghasilkan pertumbuhan dan umbi wortel terbaik. Penelitian dilakukan di Lahan STPP Malang mulai Januari sampai Mei 2017. Metode Penelitian menggunakan Rancangan Acak Lengkap (RAL) dengan 6 perlakuan konsentrasi yaitu: P0 (0 ml/liter/tanaman); P1 (45 ml/liter/tanaman); P2 (90 ml/liter/tanaman); P3(135 ml/liter/tanaman; P4 (180 ml/liter/tanaman); P5 (225 ml/liter/tanaman); P6 (270 ml/liter/tanaman). Masing-masing perlakuan diulang sebanyak 4 kali sehingga diperoleh 28 satuan percobaan. Penanaman dilakukan di polibag. Analisis data menggunakan uji anova 5\% dan uji Duncan. Hasil menunjukkan bahwa tinggi tanaman terbaik akibat perlakuan $270 \mathrm{ml} / \mathrm{liter} / \mathrm{tanaman}$ pupuk organik cair. Diameter umbi, panjang umbi dan berat segar umbi terbaik pada perlakuan 180 $\mathrm{ml} /$ liter/tanaman pupuk organik cair.
\end{abstract}

Kata Kunci: Pertumbuhan, Produksi, Wortel, Pupuk Organik Cair

\section{ABSTRACT}

Carrot is a high-value vegetable tuber in Indonesia. Increased production is done to meet market demand. This research aims to determine the concentration of the use of liquid organic fertilizer that is able to produce the best carrot tubers. The research was conducted at STPP Malang field from January to May 2017. Research Method using Completely Randomized Design with 6 treatment concentration that is: PO $(0$ ml/liter/plant); P1 (45 ml/liter/plant); P2 (90 ml/liter/plant); P3 (180 ml/liter/plant), P5 (225 $\mathrm{ml} /$ /iter/plant), P6 (270 $\mathrm{ml} /$ /iter/plant). Each treatment was repeated four times to obtain 28 experimental units. Planting is done in polybags. Data analysis used $5 \%$ anova test and Duncan test. The results showed that the best plant height due to the treatment of $270 \mathrm{ml} /$ liter/plant organic liquid fertilizer. Tuber diameter, tuber length and fresh weight of the best bulb in the treatment of 180 ml/liter/plant organic liquid fertilizer.

Key Words: Growth, Production, Carrots, Organic Liquid Fertilizer

150 | Jurnal Agriekstensia Vol. 17 No. 2 Desember 2018 


\section{PENDAHULUAN}

Wortel merupakan sayuran umbi yang kaya akan vitamin A, B kompleks, C, D, E, K, dan antioksidan. Wortel mempunyai multi khasiat bagi kesehatan diantaranya dapat mencegah penyakit rabun senja (buta ayam) dan masalah kurang gizi (Sunarjono, 2016).

Luas areal panen wortel nasional mencapai 30.762 ha yang tersebar di 16 propinsi yaitu; Jawa Barat, Jawa Tengah, Jawa Timur, Bengkulu, Sumatera Utara, Sumatera Barat, Sumatera Selatan, Lampung, Bali, NTT, Kalimantan Timur, Sulawesi Utara, Sulawesi Tengah, Sulawesi Selatan, Maluku dan Irian Jaya. Produksi nasional pada tahun 2015, sebesar 495.798 ton, dengan produktivitas 16,12 ton/ha. Produktivitas rata rata di pulau Jawa sebesar 16,04 ton /ha, dengan tingkat produksi 317.994 ton pada luas lahan sebesar 19.825 ha. Produktifitas Jawa Timur menempati urutan ketiga setelah Jawa Barat dan Jawa Tengah dengan produktivitas sebesar 14,76 ton/ha (Dirjen Hortikultura, 2015). Salah satu sentra produksi tanaman wortel di Jawa timur adalah Kecamata Bumiaji dengan luas lahan 510 ha, dengan produksi mencapai \pm 8.925 ton dan produktivitas sebesar 17,5 ton/ha (Programa Penyuluhan Pertanian Kecamatan Bumiaji 2016 dan Data Dasar Pertanian Desa Se Kecamatan Bumiaji Kota Batu 2016) .

Hasil Identifikasi potensi wilayah di Kecamatan Bumiaji Desa Tulungrejo Kelompoktani Wono Rejeki pada November 2016 bahwa luas tanam wortel 310 ha dengan produksi \pm 4.867 ton dan produktivitas sebesar 15,7 ton/ha. Produktivitas wortel pada setiap tahun terus mengalami penurunan. Hal ini disebabkan oleh beberapa faktor diantaranya tingkat kesuburan tanah yang semakin menurun akibat penggunaan pupuk anorganik dan pestisida kimia yang berlebihan dan kurangnya debit air ketika musim kemarau serta serangan hama penyakit. Dengan demikian untuk memperbaiki struktur tanah dan mengembalikan tingkat kesuburan tanah perlu memanfaatkan limbah ternak yang ada di kelompoktani Wono Rejeki. Kotoran padat/pupuk kandang merupakan sumber bahan organik. Sedangkan kotoran cair/urine merupakan bahan baku utama dalam pembuatan pupuk organik cair (Sutedjo, 2002).

Pupuk organik cair mengandung berbagai mineral, juga zat-zat esensial yang dibutuhkan tanah dan tanaman, serta hormon pertumbuhan tanaman. Unsur hara pada pupuk organik lebih mudah diserap oleh tanaman karena secara efektif meningkatkan kapasitas tukar kation pada tanah, bila dibandingkan dengan pupuk kimia. Kapasitas tukar kation adalah kemampuan tanah untuk meningkatkan interaksi antar ion-ion di dalam tanah sehingga mampu menyediakan berbagai unsur yang dibutuhkan tanaman (Patanga,2016).

Pupuk organik cair mengandung unsur hara Nitrogen dan Kalium lebih banyak dibandingkan pupuk padat. Pada kotoran sapi padat mengandung unsur hara Nitrogen $0,55 \%$, Posfor $0,30 \%$, dan Kalium 0,40\%, sedangkan unsur hara pada korotan sapi cair (urine) Nitrogen 1,40\%, Posfor 0,03\% dan Kalium 1,60\% (Lingga, 1991). Sesuai dengan pendapat Sutedjo (2002) bahwa pupuk organik cair mengandung Kalium lebih tinggi dibandingkan pupuk organik padat. Hal ini dibuktikan juga dengan hasil uji laboratorium pupuk organik cair yang digunakan mengandung unsur hara Kalium lebih tinggi (hasil uji laboratorium BPTP Jawa Timur, 2017).

Unsur hara Kalium mempunyai peranan penting dalam setiap proses metabolisme tanaman. Asam amino dan protein yang berasal dari ion-ion amonium cukup berperan dalam memelihara tekanan turgor dengan baik sehingga melancarkan proses-proses metabolisme dan menjamin kesinambungan pemanjangan sel (Purwowidodo,1993). Selain itu unsur hara Kalium berperan dalam pembentukan 
ketahanan tanaman dari serangan hama maupun penyakit (Sutedja, 2002).

Menurut Suriadikarta

menyatakan bahwa pemberian pupuk organik cair harus memperhatikan konsentrasi dalam aplikasikan terhadap tanaman. Berdasarkan hasil penelitian Taufika R (2011) bahwa dosis/konsentrasi pupuk organik cair yang terbaik adalah $135 \mathrm{ml} /$ tanaman karena mampu menghasilakn berat umbi segar yang tertinggi dari pada perlakuan lainnya ( $0 \mathrm{ml} /$ tanaman, 45 $\mathrm{ml} /$ tanaman dan 90ml/tanaman). Penulis melakukan pemberian konsentrasi pupuk organik cair yang lebih tinggi dengan harapan dapat meningkatkan produksi tanaman wortel.

\section{METODE PENELITIAN}

Penelitian dilaksanakan dilahan praktek Kampus STPP Malang. Pelaksanaan mulai bulan Januari 2017 sampai dengan bulan April 2017. Analisis kandungan unsur hara pupuk organik cair dilakukan di Laboratorium Balai Pengkajian Teknologi Pertanian (BPTP) Jawa Timur.

Bahan yang digunakan pada penelitian adalah benih wortel varietas Kuroda Ew, pupuk kandang sapi, pupuk organik cair. Alat yang digunakan pada kajian teknis adalah sekop, cangkul, ember, timbangan, alat ukur,gembor dan alat tulis menulis.

Penelitian dilakukan dengan menggunakan metode Rancangan Acak Lengkap (RAL) dengan tujuh perlakuan. Perlakuan tersebut adalah : 1) P0 (Tanpa perlakuan POC); 2) P1 (Perlakuan dengan konsentrasi $45 \mathrm{ml} / 1$ liter air/ tanaman); 3) P2 (Perlakuan dengan konsentrasi $90 \mathrm{ml} / 1$ liter air/ tanaman); 4) P3 (Perlakuan dengan konsentrasi $135 \mathrm{ml} / 1$ liter air/ tanaman); 5) P4 (Perlakuan dengan konsentrasi $180 \mathrm{ml} / 1$ liter air/ tanaman); 6) P5 (Perlakuan dengan konsentrasi $225 \mathrm{ml} / 1$ liter air/ tanaman); P6 (Perlakuan dengan konsentrasi $270 \mathrm{ml} / 1$ liter air/ tanaman).
Setiap perlakuan diulang sebanyak 4 kali sehingga diperoleh 28 satuan percobaan.

Tanaman wortel ditanam di polibag dengan diameter $35 \mathrm{~cm}$. Media tanam terdiri dari campuran pupuk kandang dan tanah dengan perbandingan 1:1. Berat media per polibag $8,5 \mathrm{~kg}$. Setiap polibag ditanami 2 tanaman tanpa dilakukan persemaian. Pemupukan susulan setiap 7 hari sekali sesuai dengan konsentrasi perlakuan. Panen dilakukan pada umur 90 hari setelah tanam dengan ciri-ciri sebagian daun sudah berwarna kuning. Panen dilakukan dengan cara mencabut tanaman wortel dan selanjutnya membersihkan umbi.

Pengamatan dilakukan terhadap: 1) tinggi tanaman (tinggi tanaman mulai pangkal batang sampai daun tertinggi); 2) Diameter umbi (rata-rata diameter umbi dari pangkal, tengah dan ujung umbi); 3) Panjang umbi (panjang umbi dari pangkal sampai ujung umbi); 4) Berat segar umbi (berat segar umbi ketika panen setelah dibersihkan dari tanah). Pengamatan tinggi tanaman dilakukan setiap 7 hari sekali. Pengamatan diameter umbi, panjang umbi dan berat segar umbi dilakukan setelah panen.

Data yang diperoleh dianalisis menggunakan Uji $\mathrm{F}$ taraf $5 \%$. Uji lanjut dilakukan dengan menggunakan uji Duncan.

\section{HASIL DAN PEMBAHASAN}

\section{Analisis Tinggi Tanaman}

Pengamatan tinggi tanaman dilakukan pada tanaman berumur 15, 22, 29, 36, 43, 50, 57, 64, 71, 78, 85 hari setelah tanam (hst). Hasil analisis statistik tinggi tanaman dapat dilihat pada Tabel 1.

Tabel 1 menunjukan bahwa tinggi tanaman sampai pengamatan ke 6 (50 HST) tidak terdapat perbedaan nyata. Hal ini di karenakan pada umur 15, 22, 29, 36, 43 ,50 hari setelah tanam, tanaman wortel belum menyuplai dan menyerap unsur hara yang terkandung dalam pupuk organik cair. Lakitan 
(2004) dalam Sarido (2013), menyatakan bahwa pada awal pertumbuhan tanaman, sebagian kandungan unsur hara belum terserap oleh tanaman. Selain itu pada fase pertumbuhan vegetatif tanaman lebih sering di pengaruhi oleh sifat genetik tanaman itu sendiri sehingga pengaruh dari luar faktor tanaman tidak terlalu berpengaruh terhadap tinggi tanaman.

Tabel 1. Rata-rata Tinggi Tanaman Wortel Akibat Pemberian Berbagai Konsentrasi POC

\begin{tabular}{|c|c|c|c|c|c|c|c|c|c|c|c|c|}
\hline \multirow{3}{*}{$\begin{array}{c}\text { Perlakuan } \\
0 \mathrm{POC}\end{array}$} & \multicolumn{12}{|c|}{ Rata - Rata Tinggi Tanaman $(\mathrm{cm})$} \\
\hline & \multicolumn{2}{|c|}{15 HST } & \multicolumn{2}{|c|}{22 HST } & \multicolumn{2}{|c|}{29 HST } & \multicolumn{2}{|c|}{36 HST } & \multicolumn{2}{|c|}{43 HST } & \multicolumn{2}{|c|}{50 HST } \\
\hline & 1,66 & $\mathrm{a}$ & 2,63 & $\mathrm{a}$ & 6,00 & $\mathrm{a}$ & 10,88 & $\mathrm{a}$ & 17,25 & $\mathrm{a}$ & 24,75 & $\mathrm{a}$ \\
\hline $45 \mathrm{ml}$ POC & 2,01 & $\mathrm{a}$ & 3,00 & $\mathrm{a}$ & 6,13 & a & 10,88 & a & 17,88 & a & 25,00 & $\mathrm{a}$ \\
\hline $90 \mathrm{ml} \mathrm{POC}$ & 1,75 & $\mathrm{a}$ & 3,31 & $\mathrm{a}$ & 6,56 & $\mathrm{a}$ & 11,00 & $\mathrm{a}$ & 17,75 & $\mathrm{a}$ & 25,50 & 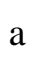 \\
\hline $135 \mathrm{ml}$ POC & 1,44 & $\mathrm{a}$ & 2,69 & $\mathrm{a}$ & 6,50 & $\mathrm{a}$ & 11,63 & $\mathrm{a}$ & 17,13 & a & 24,88 & 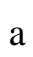 \\
\hline $180 \mathrm{ml}$ POC & 2,04 & $\mathrm{a}$ & 3,75 & $\mathrm{a}$ & 6,81 & $\mathrm{a}$ & 12,16 & $\mathrm{a}$ & 19,25 & $\mathrm{a}$ & 26,13 & $\boldsymbol{u}$ \\
\hline $225 \mathrm{ml}$ POC & 1,45 & $\mathrm{a}$ & 2,66 & $\mathrm{a}$ & 6,75 & $\mathrm{a}$ & 13,25 & $\mathrm{a}$ & 19,00 & $\mathrm{a}$ & 25,00 & . \\
\hline $270 \mathrm{ml}$ POC & 2,06 & $\mathrm{a}$ & 3,85 & $\mathrm{a}$ & 8,48 & $\mathrm{a}$ & 14,50 & $\mathrm{a}$ & 21,25 & $\mathrm{a}$ & 28,50 & $\mathrm{a}$ \\
\hline
\end{tabular}

\begin{tabular}{ccccccccccc}
\hline \multirow{2}{*}{ Perlakuan } & \multicolumn{8}{c}{ Rata - Rata Tinggi Tanaman (cm) } \\
& 57 HST & \multicolumn{1}{c}{ 64 HST } & 71 HST & 78 HST & \multicolumn{2}{c}{ 85 HST } \\
\hline 0 POC & 31,38 & a & 38,50 & a & 45,00 & a & 50,00 & a & 51,00 & a \\
$45 \mathrm{ml} \mathrm{POC}$ & 31,50 & a & 38,50 & a & 47,48 & a & 51,25 & a & 52,25 & a \\
$90 \mathrm{ml} \mathrm{POC}$ & 32,13 & a & 39,63 & a & 46,00 & a & 50,88 & a & 51,88 & a \\
$135 \mathrm{ml} \mathrm{POC}$ & 33,81 & a & 39,88 & a & 47,38 & a & 52,13 & a & 53,13 & a \\
$180 \mathrm{ml} \mathrm{POC}$ & 33,88 & a & 40,25 & a & 46,75 & a & 52,00 & a & 53,00 & a \\
$225 \mathrm{ml} \mathrm{POC}$ & 33,00 & a & 41,25 & a & 46,50 & a & 50,38 & a & 51,38 & a \\
$270 \mathrm{ml} \mathrm{POC}$ & 38,13 & b & 45,50 & b & 52,13 & b & 56,25 & b & 57,38 & b \\
\hline
\end{tabular}

Keterangan : Angka yang diikuti oleh huruf yang sama menunjukkan tidak terdapat perbedaan berdasarkan uji Duncan

Hasil pengamatan ke 7 (57 HST) sampai pengamatan ke 9 (85 HST) terdapat perbedaan yang signifikan terhadap tinggi tanaman. Perlakuan yang menghasilkan tinggi tanaman terbaik adalah $270 \mathrm{ml} / \mathrm{liter}$ air POC. $\mathrm{Hal}$ ini di pengaruhi kandungan unsur $\mathrm{N}$ yang ada dalam POC tersebut lebih tinggi dari pada perlakuan lainnya. Respon tanaman terhadap penambahan unsur $\mathrm{N}$ melalui pemupukan sangat terlihat. Hasil analisis kandungan unsur hara POC dapat dilihat pada Tabel 2.

Tabel 2. Kandungan Unsur Hara Pada Pupuk Organik Cair Urine Sapi

\begin{tabular}{cc}
\hline Unsur Hara & Nilai \\
\hline Nitrogen & $0,15 \%$ \\
$\mathrm{P}_{2} \mathrm{O}_{5}$ & $0,01 \%$ \\
$\mathrm{~K}_{2} \mathrm{O}$ & $0,18 \%$
\end{tabular}

Hasil Uji di Laboratorium Tanah BPTP Jawa Timur April 2017

Menurut Lakitan, (2009) menjelaskan bahwa unsur $\mathrm{N}$ atau nitrogen bermanfaat untuk pertumbuhan vegetatif tanaman yakni pembentukan sel sel baru seperti daun, cabang, umbi/akar dan mengganti sel yang rusak. Lebih lanjut Rosliani, dkk (1998) menyatakan penambahan unsur hara berupa pupuk organik cair sangat penting untuk pertumbuhan 
tanaman. Hal ini berarti jumlah unsur hara yang diserap berada dalam jumlah yang cukup, dengan demikian dapat meningkatkan tinggi tanaman.

\section{Analisis Diameter Umbi}

Umbi adalah bagian yang paling bernilai ekonomis pada tanaman wortel. Berdasarkan uji $\mathrm{F}$ terdapat perbedaan yang nyata antara perlakuan berbagai konsentrasi POC urine sapi terhadap diameter umbi wortel. Rata-rata diameter umbi wortel dapat dilihat pada Tabel 3.

Tabel 3. Rata-rata Diameter Umbi Tanaman Wortel Akibat Pemberian Berbagai Konsentrasi Pupuk Organik Cair

\begin{tabular}{cccc}
\hline Perlakuan & Diameter Umbi Wortel $(\mathbf{c m})$ & \\
\hline 0 POC & 2,688 & $\mathrm{a}$ \\
$45 \mathrm{ml}$ POC & 3,194 & $\mathrm{a}$ \\
$90 \mathrm{ml}$ POC & 2,834 & $\mathrm{a}$ \\
$135 \mathrm{ml}$ POC & 2,663 & $\mathrm{a}$ \\
$180 \mathrm{ml}$ POC & 3,475 & $\mathrm{~b}$ \\
$225 \mathrm{ml}$ POC & 3,625 & $\mathrm{~b}$ \\
$270 \mathrm{ml}$ POC & 2,813 & $\mathrm{a}$ \\
\hline
\end{tabular}

Keterangan : Angka yang diikuti oleh huruf yang sama menunjukkan tidak terdapat perbedaan berdasarkan uji Duncan

Diameter umbi wortel tertinggi adalah akibat penggunaan POC urine sapi dengan konsentrasi 225 dan $180 \mathrm{ml}$ per tanaman. Konsentrasi POC Urine sapi $180 \mathrm{ml}$ per tanaman dan $225 \mathrm{ml}$ pertanaman mempu mencukupi unsur hara untuk pembentukan umbi sehingga pengisian dan pembesaran optimal dari perlakuan lainnya. Penggunaan POC dengan konsentrasi yang lebih tinggi (270) mendorong pertumbuhan vegetatif tanaman seperti tinggi tanaman. Unsur hara $\mathrm{N}$ yang lebih tinggi pada POC sangat mendukung pertumbuhan vegetatif tanaman namun tidak menghasilkan diameter umbi yang lebih baik.

\section{Panjang Umbi}

Pengamatan panjang umbi dilakukan sesaat setelah panen. Hasil analisis statistik atau uji $\mathrm{F}$ menunjukan bahwa terdapat perbedaan nyata antara perlakuan terhadap panjang umbi wortel. Rata-rata panjang umbi wortel dapat dilihat pada Tabel 4.

Tabel 4. Rata-rata Panjang Umbi Tanaman Wortel Akibat Pemberian Berbagai Konsentrasi Pupuk Organik Cair

\begin{tabular}{ccc}
\hline Perlakuan & Panjang Umbi Wortel $(\mathbf{c m})$ & \\
\hline 0 POC & 11,50 & $\mathrm{a}$ \\
$45 \mathrm{ml} \mathrm{POC}$ & 13,65 & $\mathrm{a}$ \\
$90 \mathrm{ml}$ POC & 13,44 & $\mathrm{a}$ \\
$135 \mathrm{ml}$ POC & 11,04 & $\mathrm{a}$ \\
$180 \mathrm{ml}$ POC & 15,69 & $\mathrm{~b}$ \\
$225 \mathrm{ml}$ POC & 16,24 & $\mathrm{~b}$ \\
$270 \mathrm{ml} \mathrm{POC}$ & 12,13 & $\mathrm{a}$ \\
\hline
\end{tabular}

Keterangan : Angka yang diikuti oleh huruf yang sama menunjukkan tidak terdapat perbedaan berdasarkan uji Duncan 
Tabel 4 menunjukkan panjang umbi pada perlakuan dengan konsentrasi $180 \mathrm{ml}$ per tanaman dan $225 \mathrm{ml}$ per tanaman menghasilkan panjang umbi yang lebih baik dari pada perlakuan lainnya. Kedua perlakuan tersebut mampu menyediakan usur hara yang cukup untuk pertmbuhan umbi wortel. Pemberian POC yang unsur haranya lebih mudah diserap oleh tanaman dibandingkan pupuk padat. Unsur hara $\mathrm{K}$ dan unsur hara $\mathrm{P}$ berperan dalam pembentukan umbi. Unsur P dan K merupakan unsur yang sangat dibutuhkan tanaman untuk merangsang perakaran yang kuat, memanjang dan tahan kekeringan (Soewito,1991 dalam Taufika R,2011)

Berbeda dengan perlakuan POC dengan konsentrasi yang lebih tinggi $270 \mathrm{ml}$ per tanaman. semakin tinggi konsentrasi POC yang diberikan maka jumlah unsur hara nitrogen $(\mathrm{N})$ akan tersedia lebih banyak bagi tanaman. Akibatnya pertumbuhan vegetatif tanaman wortel lebih baik. Hasil fotosintesis lebih dialokasikan lebih banyak ke bagian pucuk tanaman sehingga pembentukan umbi kalah dengan pertumbuhan tinggi tanaman. Menurut Suwito (1991) dalam Rahmi Taufika (2011) kelebihan unsur hara N pada fase generatif akan merangsang pertumbuhan daun daripada pembentukan umbi.

\section{Analisis Berat Umbi}

Berat umbi adalah penentu kuantitas produksi wortel. Hasil analisis statistik menunjukkan terdapat perbedaan yang nyata antara perlakuan terhadap berat umbi wortel. Rata-rata berat umbi wortel dapat dilihat pada Tabel 5.

Tabel 5. Rata-rata Berat Umbi Tanaman Wortel Akibat Pemberian Berbagai Konsentrasi Pupuk Organik Cair

\begin{tabular}{ccc}
\hline Perlakuan & Berat Umbi Wortel Per Tanaman $(\mathbf{g})$ & \\
\hline 0 POC & 83,25 & $\mathrm{a}$ \\
$45 \mathrm{ml}$ POC & 103,50 & $\mathrm{~b}$ \\
$90 \mathrm{ml}$ POC & 93,38 & $\mathrm{a}$ \\
$135 \mathrm{ml}$ POC & 78,00 & $\mathrm{a}$ \\
$180 \mathrm{ml}$ POC & 123,13 & $\mathrm{c}$ \\
$225 \mathrm{ml}$ POC & 137,75 & $\mathrm{c}$ \\
$270 \mathrm{ml}$ POC & 96,13 & $\mathrm{a}$ \\
\hline
\end{tabular}

Keterangan : Angka yang diikuti oleh huruf yang sama menunjukkan tidak terdapat perbedaan berdasarkan uji Duncan

Berat umbi terbaik akibat perlakuan POC $180 \mathrm{ml}$ per tanaman dan $225 \mathrm{ml}$ per tanaman. keseimbangan unsur hara yang tersedia bagi tanaman sangat menentukan pertumbuhan tanaman. Perlakuan $180 \mathrm{ml}$ per tanaman dan $225 \mathrm{ml}$ per tanaman mampu memberikan unsur hara $\mathrm{P}$ dan $\mathrm{K}$ yang lebih dominan dari pada unsur N. Unsur har P dan $\mathrm{K}$ memacu pembentukan umbi, akar, bunga dan pembesaran buah. walaupun sudah memasuki fase generatif tetapi ketersediaan unsur hara masih dominan unsur hara nitrogen akan sangat mempengaruhi pertumbuhan vegetatif tanaman. namun ketika fase generatif ketersediaan unsur hara $\mathrm{N}$ hanya secukupnya dan unsur $\mathrm{P}$ dan $\mathrm{K}$ lebih berperan maka akan mendorong pertumbuhan generatif atau hasil tanaman (umbi). Menurut Munawar (2011) unsur hara K mampu mengaktifkan enzim-enzim yang berperan pada proses fotosintesis dan mengatur kelancaran buka tutupnya stomata. Selain itu 
unsur hara $\mathrm{K}$ juga mampu memperlancar proses translokasi hasil fotosintesis ke bagian umbi tanaman wortel. Menurut Sutedja (2002) unsur hara $\mathrm{K}$ mempu membentuk tanaman yang tahan terhadap hama dan penyakit. Hal ini terbukti bahwa wortel yang diperlakukan tidak terserang hama atau penyakit yang dapat merugikan secara ekonomis.

\section{KESIMPULAN}

1. Pertumbuhan wortel (tinggi tanaman) yang terbaik adalah akibat perlakuan Penambahan POC $270 \mathrm{ml}$ per tanaman.

2. Produksi wortel (diameter umbi, panjang umbi dan berat umbi) terbaik adalah akibat perlakuan penambahan POC 180 $\mathrm{ml}$ per tanaman dan $225 \mathrm{ml}$ per tanaman. untuk efisiensi penggunaan POC maka dengan menggunakan PPOC $180 \mathrm{ml}$ per tanaman sudah mempu memberikan hasil yang optimal dibandingkan perlakuan lainnya.

\section{DAFTAR PUSTAKA}

Arief Patanga, A. 2016. Pembuatan, Aplikasi dan Bisnis Pupuk Organik dari Limbah Peternakan dan Rumah Tangga. Pt Gramedia Pustaka Utama Jakarta.

Badan Pusat Statistik Republik Indonesia. 2014

Kementerian Pertanian Direktorat Jenderal Hortikultura 2015. Luas Panen, Produksi dan Produktivitas Wortel. http://www.deptan.go.id/renbangtan/r ancangan $\% 20$ renstra\%20deptan\%020102014\%20lengkap.pdf. Di unduh tanggal 26 Maret 2012. Akses $02 / 12 / 2016$
Lakitan, B 2004. Dasar - Dasar Fisiologis Tumbuhan. Pt Raja Grafindo Persada Jakarta.

Lakitan, B. 2009. Dasar-Dasar Fisiologi Tumbuhan. Jakarta: PT Raja Grafindo Persada.

Munawar, A. 2011. Kesuburan Tanah dan Nutrisi Tanaman. Bogor: IPB Press.

Poerwowidodo, M. 1993. Telaah Kesuburan Tanah. Angkasa Bandung

BPP Kecamatan Bumiaji. 2016. Programa Penyuluhan Pertanian Kecamatan Bumiaji 2016 dan Data Dasar Pertanian Desa Se Kecamatan Bumiaji Kota Batu.

Sunarjono, H. 2016. Bertanam 36 Jenis Sayuran. Penerbit Penebar Swadaya Jakarta

Suriadikara, 2006. Pupuk Organik dan Pupuk Hayati. Balai Besar Penelitian dan Pengembangan. Jawa Barat

Sutedjo, M. 2002. Pupuk dan Cara Pemupukan. Rineka cipta. Jakarta.

Taufika, R 2011. Pengujian Beberapa Dosis Pupuk Organik Cair terhadap Pertumbuhan Dan Hasil Tanaman Wortel (Daucus carota L.). 2011 Jurnal penelitian akses 16/10/2016. 